\title{
PENGARUH PENAMBAHAN GLISEROL TERHADAP SIFAT MEKANIK FILM PLASTIK BIODEGRADASI DARI PATI KULIT SINGKONG
}

\author{
Zulisma Anita, Fauzi Akbar, Hamidah Harahap \\ Departemen Teknik Kimia, Fakultas Teknik, Universitas Sumatera Utara, \\ Jl. Almamater Kampus USU, Medan 20155, Indonesia \\ Email : zulismaanitalubis@yahoo.co.id
}

\begin{abstract}
Abstrak
Biodegradable plastik adalah plastik yang akan terurai di alam dengan bantuan mikroorganisme. Penggunaan pati sebagai bahan utama pembuatan plastik memiliki potensi yang besar karena di Indonesia terdapat berbagai tanaman penghasil pati. Untuk memperoleh bioplastik, pati ditambahkan dengan plastisizer gliserol, sehingga diperoleh plastik yang lebih fleksible dan elastis. Penelitian ini mengkaji tentang pemanfaatan pati kulit singkong dan gliserol sebagai bahan dasar pembuatan biodegradable plastik. Tujuan dari penelitian ini yaitu mengetahui pengaruh penambahan gliserol pada proses pembuatan plastik biodegradable dari limbah kulit singkong. Dalam penelitian ini dilakukan studi mengenai pembuatan bioplastik campuran pati dengan gliserol sebagai plastisizer dengan melakukan variasi terhadap volume gliserol. Hasil yang diperoleh berupa lembaran tipis plastik (film plastik) yang telah diuji sifat mekaniknya didapatkan variabel data optimum yaitu komposisi pati kulit singkong sebanyak 12 gram dengan penambahan gliserol $4 \mathrm{ml}$ dengan nilai pemanjangan saat putus 3,5\%, kekuatan tarik 0,02122 Mpa dan waktu penyimpanan film plastik selama 14 hari.
\end{abstract}

Kata kunci : biodegradasi, film plastik, plastisizer

\begin{abstract}
Biodegradable plastics are plastics that will decompose in nature with the help of microorganisms. The use of starch as the main material of plastic manufacturing has great potential because in Indonesia there are different starch crops. To obtain bioplastics, starch is added to the glycerol, in order to obtain a more flexible plastic and elastic. This study reviews the use of cassava starch and glycerol skin asa base for the manufacture of biodegradable plastics. The purpose of this research is to know the effect of adding glycerol in the process of making biodegradable plastic from cassava peel waste. In this research, the study of bioplastic manufacturing mixed starch with glycerol as a plastisizer to do variations of the glycerol. The results obtained in the form of a thin sheet of plastic (plastic film) that have been tested mechanical properties obtained optimum data variables namely cassava starch composition 3,5\%, and the power og pull 0,02122Mpa, and plastic film storage time for 14 days.
\end{abstract}

Keywords: biodegradable, film plastic, plasticizers

\section{Pendahuluan}

Penggunaan plastik sebagai bahan pengemas menghadapi berbagai persoalan lingkungan, yaitu tidak dapat didaur ulang dan tidak dapat diuraikan secara alami oleh mikroba di dalam tanah, sehingga terjadi penumpukan sampah plastik yang dapat menyebabkan pencemaran dan kerusakan bagi lingkungan [10]. Kelemahan lain adalah bahan utama pembuat plastik yang berasal dari minyak bumi, yang keberadaannya semakin menipis dan tidak dapat diperbaharui. Seiring dengan persoalan ini, maka penelitian bahan kemasan diarahkan pada bahanbahan organik, yang dapat dihancurkan secara alami dan mudah diperoleh [9]. Kandungan pati yang berasal dari kulit singkong yang cukup tinggi memungkinkan digunakan sebagai film plastik biodegradasi. Potensi tersebut dapat digunakan sebagai peluang untuk memberikan nilai tambah pada kulit singkong sebagai bahan dasar dalam pembuatan kemasan plastik yang ramah lingkungan [6].

Permasalahan pokok yang akan dijawab dalam penelitian ini adalah apakah pati kulit singkong dapat digunakan sebagai bahan baku pembuatan film plastik biodegradasi. Untuk itu dirumuskanlah bagaimana formula dan karakteristik kemasan film plastik biodegradasi dari pati kulit singkong dapat dibuat.

\section{Teori}

Plastik biodegradable adalah plastik yang dapat digunakan seperti layaknya plastik konvensional, namun akan hancur terurai oleh aktivitas mikroorganisme menjadi air dan karbondioksida setelah habis terpakai dan 
dibuang ke lingkungan. Karena sifatnya yang dapat kembali ke alam, maka dikategorikan sebagai plastik yang ramah lingkungan. Jepang telah menyepakati penggunaan nama plastik hijau (guriinpura) untuk plastik biodegradasi [3]. Berdasarkan bahan baku yang dipakai plastik biodegradasi dibagi menjadi dua kelompok yaitu kelompok dengan bahan baku petrokimia dan kelompok dengan bahan baku produk tanaman seperti pati dan selulosa [6]. Pembentukan film plastik dari pati, pada prinsipnya merupakan gelatinasi molekul pati. Pembuatan film berbasis pati pada dasarnya menggunakan prinsip gelatinasi. Dengan adanya penambahan sejumlah air dan dipanaskan pada suhu yang tinggi maka akan terjadi gelatinasi. Gelatinasi mengakibatkan ikatan amilosa akan cenderung saling berdekatan karena adanya ikatan hidrogen. Proses pengeringan akan mengakibatkan penyusutan sebagai akibat lepasnya air sehingga gel akan membentuk film yang stabil [4]. Karakteristik film yang dapat diuji adalah karakteristik mekanik, permeabilitas dan nilai biodegradabilitasnya. Karakteristik mekanik suatu film kemasan terdiri dari : kuat tarik (tensile strength), persen pemanjangan (elongation to break) dan elastisitas (elastic/young modulus). Parameter-parameter tersebut dapat menjelaskan bagaimana karakteristik mekanik dari bahan film yang berkaitan dengan struktur kimianya. Permeabilitas suatu film kemasan adalah kemampuan melewatkan partikel gas dan uap air pada suatu unit luasan bahan pada suatu kondisi tertentu.yang belum mengalami proses aktivasi. Beberapa faktor yang mempengaruhi tingkat biodegradabilitas kemasan setelah kontak dengan mikroorganisme, yakni : sifat hidrofobik, bahan aditif, proses produksi, struktur polimer, morfologi dan berat molekul bahan kemasan. Proses terjadinya biodegradasi film kemasan pada lingkungan alam dimulai dengan tahap degradasi kimia yaitu dengan proses oksidasi molekul, menghasilkan polimer dengan berat molekul yang rendah [2].

Pati adalah karbohidrat yang merupakan polimer glukosa yang terdiri dari amilosa dan amilopektin dengan perbandingan 1:3 (besarnya perbandingan amilosa dan amilopektin ini berbeda-beda tergantung jenis patinya. Kandungan amilosadan amilopektin pati kulit singkong adalah 15/73[4]).

Plastisizer (bahan pelembut) adalah bahan organik dengan berat molekul rendah yang ditambahkan pada suatu produk dengan tujuan untuk menurunkan kekakuan dari polimer, sekaligus meningkatkan fleksibilitas dan ekstensibilitas polimer. Pada pembuatan biodegradable plastik ini sangat diperlukan sekali adanya plasticizer untuk memperoleh sifat film yang khusus [11].

Kekuatan tarik adalah gaya tarik maksimum yang dapat ditahan oleh film selama pengukuran berlangsung. Kekuatan tarik dipengaruhi oleh bahan pemplastis yang ditambahkan dalam proses pembuatan film. Sedangkan persen pemanjangan saat putus merupakan perubahan panjang maksimum film sebelum terputus. Berlawanan dengan itu, elastisitas akan semakin menurun seiring dengan meningkatnya jumlah bahan pemplastis dalam film. Elastisitas merupakan ukuran dari kekuatan film yang dihasilkan [5].

\section{Metodologi Penelitian}

Dalam proses pembuatan film plastik, terlebih dahulu dibuat bahan baku yaitu pati kulit singkong yang kering. Proses pembuatan pati kulit singkong diawali dengan cara membersihkan kulit singkong sebanyak 100 gram sehingga dihasilkan kulit singkong bersih dan putih. Lalu ditambahkan $100 \mathrm{ml}$ air yang berfungsi untuk mempermudah penghancuran. Proses penghancuran kulit singkong dilakukan dengan alat blender. Bubur kulit singkong yang telah didapat kemudian disaring dan dibiarkan selama 30 menit untuk mendapatkan endapan dari bubur kulit singkong. Jika sudah 30 menit endapan dipisahkan dari air, kemudian endapan yang diperoleh ditambahkan lagi dengan air dan diendapkan kembali dengan waktu yang sama yaitu 30 menit. Endapan yang didapat kemudian dikeringkan didalam oven dengan suhu $70^{\circ} \mathrm{C}$ selama 30 menit. Setelah didapat pati kering dari persiapan bahan baku, selanjutnya proses pembuatan film plastik biodegradable.

Pati kulit singkong sebanyak 12 gram dimasukkan kedalam beaker glass, kemudian ditambahkan $25 \mathrm{ml}$ air. Setelah diperoleh campuran pati kulit singkong dengan air, tambahkan $3 \mathrm{ml}$ asam asetat yang berfungsi sebagai pelarut, kemudian ditambahkan kembali $2 \mathrm{ml}$ gliserol yang berfungsi sebagai plastisizer lalu campuran tersebut dipanaskan sambil diaduk didalam waterbath selama 30 menit. Dicetak diatas cetakan yang berbahan dasar polietilen. Kemudian dikeringkan pada suhu ruangan selama 24 jam.

Film plastik yang dihasilkan diuji sifat mekanik seperti kekuatan tarik, pemanjangan saat putus dan modulus young dengan menggunakan alat autograph-sidmazu berdasarkan ASTM D638. Kemudian sampel terbaik atau sifat mekanik paling baik dilakukan 
uji biodegradasi di dalam tanah dan diletakkan diatas tanah. Ukuran spesimena adalah $10 \times 200$ $\mathrm{x} 1 \mathrm{~mm}$. Spesimen ditanam dalam tanah dengan kedalaman $30 \mathrm{~cm}$. Sebelum penanaman ditimbang terlebih dahulu. Waktu petik dilakukan perminggu. Berat yang hilang dari setiap spesimen dihitung dengan persamaan:

Berat yang hilang $=\frac{a 1-a 2}{a 1}$

Dimana : $\mathrm{a}_{1}=$ berat sebelum penanaman

$$
\mathrm{a}_{2}=\text { berat setelah penanaman }
$$

\section{Hasil dan Pembahasan}

Parameter yang dapat menentukan kualitas film plastik biodegradasi adalah sifat mekanik film plastik yang terdiri dari kekuatan tarik (tensile strength), persen pemanjangan saat putus (elongation to break) dan elastisitas (elastik/young modulus)[2].

Gambar 1 menunjukkan hubungan antara volume gliserol dengan kekuatan tarik dimana kekuatan tarik terbaik adalah pada 12 gram pati dan $4 \mathrm{ml}$ gliserol.

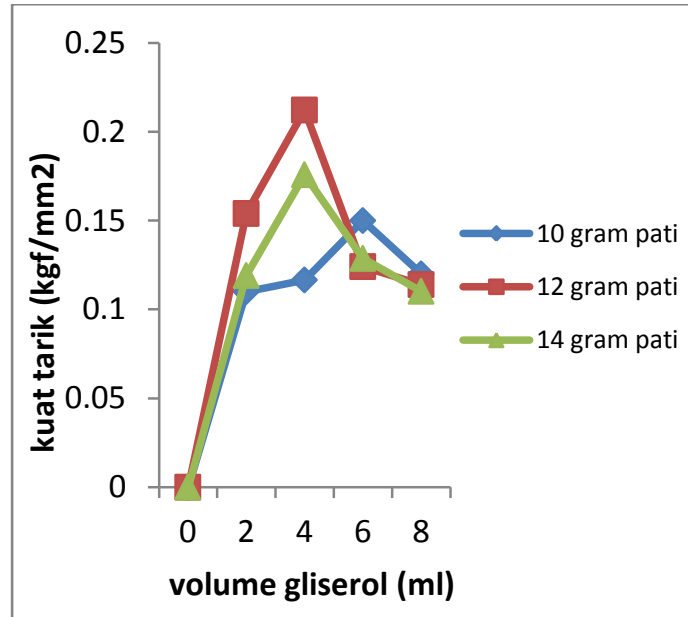

Gambar 1. Pengaruh volume gliserol dan berat pati terhadap kekuatan tarik film plastik

Gambar 2 menunjukkan dengan penambahan gliserol pemanjangan saat putus akan semakin meningkat. Tetapi pada saat penambahan $6 \mathrm{ml}$ gliserol terjadi penurunan yang disebabkan pati dan gliserol tidak terdistribusi dengan sempurna.

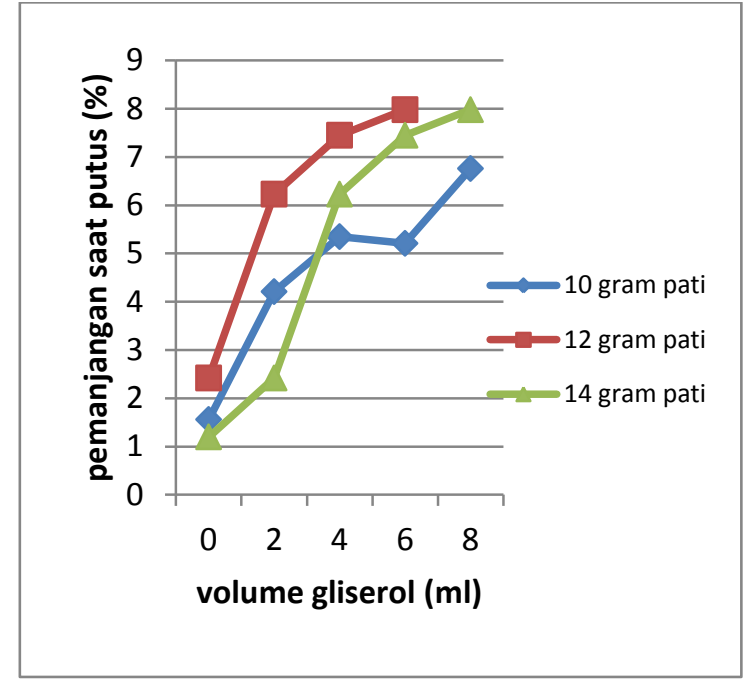

\section{Gambar 2. Pengaruh penambahan gliserol} terhadap pemanjangan saat putus

Pada gambar 3 dapat dilihat modulus young semakin menurun dengan penambahan gliserol. Hal ini disebabkan gliserol sebagai plastisizer dapat meningkatkan persentase pemanjangan dan penurunan kekuatan tarik [1].

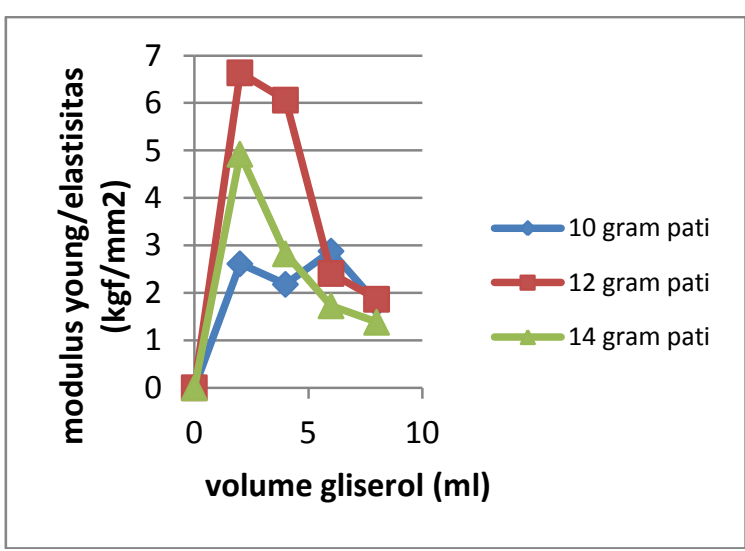

\section{Gambar 3. Pengaruh penambahan gliserol terhadap modulus young/elastisitas}

Gambar 4 menunjukkan perbandingan biodegradabilitas antara metode soil burial tes (sampel ditanam didalam tanah) dan sampel diletakkan di atas tanah. Dari gambar terlihat bahwa tingkat biodegradabilitas dari film plastik yang ditanam didalam tanah lebih tinggi dibandingkan daripada sampel yang diletakkan diatas tanah dimana fraksi berat yang sisa semakin menurun dengan bertambahnya waktu. Hal tersebut dapat terjadi karena gliserol dan pati memiliki gugus $\mathrm{OH}$ yang dapat menginisiasi reaksi hidrolisis setelah mengabsorbsi air dari tanah. Sehingga polimer pati akan 
terdekomposisi menjadi potongan-potongan kecil hingga menghilang dalam tanah. Polimer akan terdegradasi karena proses kerusakan atau penurunan mutu akibat putusnya ikatan rantai pada polimer [7]

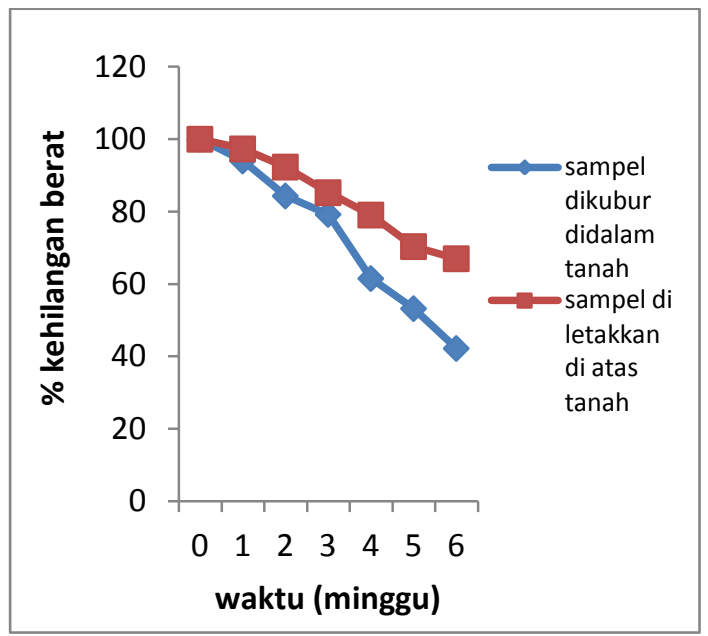

Gambar 4. Grafik pengaruh waktu terhadap berat film plastik

Pengamatan dengan spektra infra merah (IR) dilakukan dengan menggunakan FTIR (Fourier Transmitter Infra Red) Shimadzu. Spektra IR pati kulit singkong dengan film plastik pati kulit singkong ditampilkan pada gambar 5 dan 6.

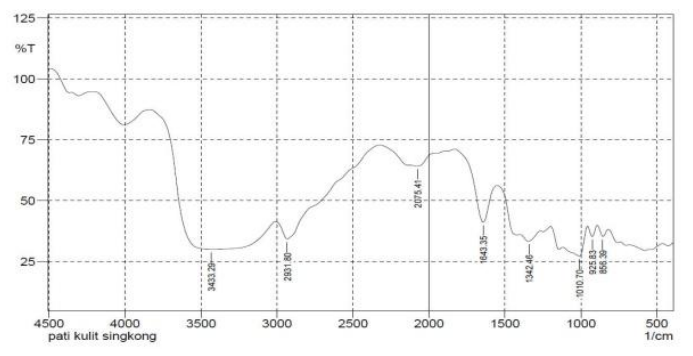

Gambar 5. Pati kulit singkong

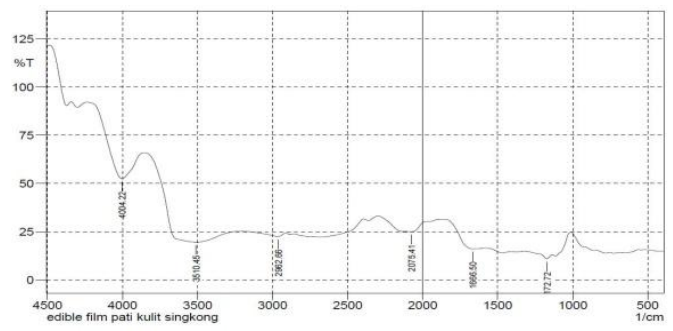

Gambar 6. Film plastik pati kulit singkong
Tabel 1. Puncak vibrasi IR dari penunjukan untuk Pati kulit singkong dan film plastik pati kulit singkong [8]

\begin{tabular}{|c|c|}
\hline $\begin{array}{l}\text { Panjang gelombang } \\
\left(\mathrm{cm}^{-1}\right)\end{array}$ & Gugus fungsi \\
\hline \multicolumn{2}{|l|}{ Pati kulit singkong } \\
\hline $3700-3100$ & $\begin{array}{l}\text { Regang } \mathrm{OH} \text { dengan } \\
\text { penyerapan air }\end{array}$ \\
\hline $3200-2850$ & Regang C-H \\
\hline $2700-1850$ & Regang ikatan ganda tiga \\
\hline $1950-1550$ & Ikatan ganda dua \\
\hline $1400-1300$ & Regang ikatan tanpa C \\
\hline $1300-1000$ & $\begin{array}{l}\text { Lentur } \\
\text { bidang }\end{array}$ \\
\hline $1215-690$ & Lentur $\mathrm{CH}$ diluar bidang \\
\hline \multicolumn{2}{|l|}{$\begin{array}{l}\text { Film plastik pati kulit } \\
\text { singkong }\end{array}$} \\
\hline $3700-3100$ & Regang $\mathrm{OH}$ \\
\hline $3200-2850$ & Regang C-H \\
\hline $2700-1850$ & $\begin{array}{l}\text { Vibrasi regang ikatan } \\
\text { ganda }\end{array}$ \\
\hline $1690-1600$ & Ikatan ganda dua \\
\hline $1000-1300$ & $\begin{array}{l}\text { Lentur } \\
\text { bidang }\end{array}$ \\
\hline
\end{tabular}

Pada Gambar 5 dan Gambar 6, hasil identifikasi gugus fungsi dengan spektrofotometer FT-IR, film plastik pati kulit singkong menunjukkan pola serapan pada daerah bilangan gelombang yang mirip dengan pati kulit singkong dimana terdapat gugus $\mathrm{C}-\mathrm{H}, \mathrm{C}=\mathrm{C}$ dan $\mathrm{OH}$. Hal ini berarti tidak ditemukannya gugus fungsi baru sehingga film plastik pati memiliki sifat-sifat seperti komponen penyusunnya.

\section{Kesimpulan}

Dari hasil penelitian diperoleh sifat mekanik yang terbaik adalah 12 gram pati, $4 \mathrm{ml}$ gliserol dengan kekuatan tarik 0,02122 Mpa dan persen pemanjangan saat putus $3,5 \%$. Film plastik terdegradasi didalam tanah selama 2 minggu ( 14 hari).

\section{Daftar Pustaka}

[1] Ani Purwanti, Analisis kuat Tarik dan Elongasi Plastik Khitosan terplastisasi Sorbitol, Institut Sains \& Teknilogi AKPRIND, Yokyakarta, 2010.

[2] Bertolini, Starches, characterization, properties, and applications, CRC Press, New York, 2010. 
[3] Charles, A.Harper., Modren Plastick Handbook, Mc-Graw-Hill, Lutherville, Maryland, 1999.

[4] Cui, S.W, Food Carbohidrates Chemistry Physic, Properties, and Aplications, CRC Press, New York, 2005.

[5] David K Platt, Biodegradable Polymers, Smithers Raphra limited, United Kingdom roy, New York, 1984.

[6] Firdaus Feris, Chairil Anwar, Potensi Limbah Padat Cair Industri Tepung Tapioka Sebagai Bahan Baku Film Plastik Biodegradable, Logika Volume I No 2, 2004.

[7] Marbun S, Sintesis Bioplastik dari pati ubi jalar menggunakan penguat logam $\mathrm{ZnO}$ dan Penguat alami sellulosa, Skripsi Fakultas Teknik, Universitas Indonesia, Jakarta, 2012.

[8] Noerdin Dasli, Elusidasi Struktur Senyawa Organik, Angkasa, Bandung, 1985.

[9] Pranamuda, Pengembangan Bahan Plastik Biodegradabel Berbahan baku Pati Tropis, http://wwwstd.ryu.titech.ac.jp/

indonesia/zoa/paper/htmL/paper Hardaning Pranamuda. htmL 2009 diakses 12 november 2011.

[10] Syamsir, E., Plastik dari senyawa limonene, 2008. http: // www.chem-istry.org/ artikel (diakses 09 November 2011.

[11] Srikhant Pilla, Handbook of bioplastics and biocomposites engineering applications, University of Wisconsin-Madison, USA, 2011. 